\title{
Recruitment Maneuver Does not Increase the Risk of Ventilator Induced Lung Injury
}

\author{
ibrahim Özkan Akıncı', Korkut Atalan', Simru Tuğrul', Perihan Ergin Özcan', Dilek Yılmazbayhan², Bayram Kıran³,
} Ahmet Basel ${ }^{1}$, Lutfi Telci' ${ }^{1}$ Nahit Çakar ${ }^{1}$

${ }^{1}$ Department of Anaesthesiology and Intensive care, Istanbul University İstanbul Medical Faculty, Istanbul, Turkey

${ }^{2}$ Department of Pathology, İstanbul University İstanbul Medical Faculty, İstanbul, Turkey

${ }^{3}$ Department of Immunology, Experimental Medicine Research Institute, Istanbul University Istanbul Medical Faculty, İstanbul, Turkey

\begin{abstract}
Background: Mechanical ventilation (MV) may induce lung injury.

Aims: To assess and evaluate the role of different mechanical ventilation strategies on ventilator-induced lung injury (VILI) in comparison to a strategy which includes recruitment manoeuvre (RM).

Study design: Randomized animal experiment.

Methods: Thirty male Sprague-Dawley rats were anaesthetised, tracheostomised and divided into 5 groups randomly according to driving pressures; these were mechanically ventilated with following peak alveolar opening (Pao) and positive end-expiratory pressures (PEEP) for 1 hour:

Group 15-0: $15 \mathrm{cmH}_{2} \mathrm{O}$ Pao and $0 \mathrm{cmH}_{2} \mathrm{O}$ PEEP; Group 30-10: $30 \mathrm{cmH}_{2} \mathrm{O}$ Pao and $10 \mathrm{cmH}_{2} \mathrm{O}$ PEEP; Group $30-5: 30 \mathrm{cmH}_{2} \mathrm{O}$ Pao and $5 \mathrm{cmH}_{2} \mathrm{O}$ PEEP; Group 30-5\&RM: $30 \mathrm{cmH}_{2} \mathrm{O}$ Pao and $5 \mathrm{cmH}_{2} \mathrm{O}$ PEEP with additional $45 \mathrm{cmH}_{2} \mathrm{O}$ CPAP for 30 seconds in every 15 minutes; Group $45-0$ : $45 \mathrm{cmH}_{2} \mathrm{O}$ Pao and $0 \mathrm{cmH}_{2} \mathrm{O}$ PEEP

Before rats were sacrificed, blood samples were obtained for the evaluation of cytokine and chemokine levels; then, the lungs were subsequently processed for morphologic evaluation.

Results: Oxygenation results were similar in all groups; however, the groups were lined as follows according to the increasing severity of morphometric

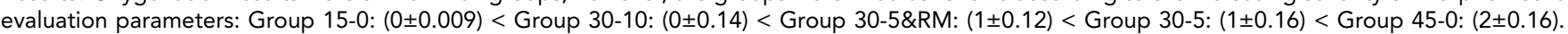
Besides, inflammatory responses were the lowest in 30-5\&RM group compared to all other groups. TNF- $\alpha$, IL-1 $\beta$, IL-6, MCP-1 levels were significantly different between group 30-5\&RM and group 15-0 vs. group 45-0 in each group.
\end{abstract}

Conclusion: RM with low PEEP reduces the risk of ventilator-induced lung injury with a lower release of systemic inflammatory mediators in response to mechanical ventilation.

Key Words: Recruitment manoeuvre, ventilator-induced lung injury, TNF- $\alpha$, IL-1 $\beta$, IL-6, MCP-1

Received: 25.07.2012

Accepted: 15.11.2012

\section{Introduction}

Mechanical ventilation is the most frequently used supportive treatment in intensive care units. However, there are increasing evidences that mechanical ventilation may induce lung injury (1); therefore, pressure limited ventilation strategies like lower tidal volumes with increasing positive endexpiratory pressure (PEEP) levels, and prone positioning have been developed to reduce ventilator-induced lung injury (VILI). Animal experiments have repeatedly demonstrated that mechanical ventilatory settings are important determinants of VILI (1). Recently, a large clinical trial that consisted of 861 Acute lung injury/Acute respiratory distress syndrome (ALI/ARDS) patients showed that a low tidal volume (VT, 6mL/ $\mathrm{kg}$ ) as compared to a high tidal volume $(12 \mathrm{~mL} / \mathrm{kg})$ setting during mechanical ventilation significantly decreased mortality (2). Amato et al. (3) were the first group to demonstrate that the mechanical ventilation strategy is an important de- terminant of mortality in ARDS patients. They proposed to set PEEP based on the inflation pressure volume (PV) curve's lower inflection point, and limit VT to maintain end-inflation plateau pressures under the upper inflection point of the P-V curve. In this study, sustained inflation manoeuvres were used to recruit collapsed lung units after suctioning or loss of PEEP (3). In accordance with this study, the routine limitation of inspiratory pressure does not necessarily improve outcome $(4,5)$. It is also recommended to use intermittent recruitment manoeuvres like sustained inflation or sigh for improving oxygenation and protecting the lungs from injury due to shear stresses of repetitive opening and closing (6-9)

Rimensberger et al. (10) have previously shown that low PEEP levels (lower than inflection point) with sustained inflation are protective against the augmentation of injury in surfactant-depleted rabbit lung. However, lung diseases that necessitate mechanical ventilation, like ALI and ARDS, are not diffuse and consist of healthy and damaged lung regions (11).

Address for Correspondence: Dr. Ibrahim Özkan Akıncı, Department of Anaesthesiology and Intensive Care, Istanbul University Istanbul Medical Faculty, Monoblok, Capa, Istanbul, Turkey Phone: +902126318767 e-mail: iozkana@yahoo.com 
Recently it has been shown that recruitment manoeuvre (RM) in a healthy rat model RM does not cause bacterial translocation (12). However, the role of RM in inducing VILI is not clear.

We hypothesised that RM does not induce VILI. To test this hypothesis we compared different mechanical ventilation strategies with different PEEP and peak airway pressures against a strategy which includes RM.

\section{Materials and Methods}

\section{Animal Preparation}

The study protocol was approved by the Istanbul University, Experimental Medicine and Research Institute, Animal Investigation Committee. Thirty male 250-300 g SpragueDawley rats were used. After the induction of anaesthesia (1$2 \%$ enflurane (Ethrane, Abbott Labs., North Chicago, USA), $35 \%$ nitrous oxide, $65 \%$ oxygen) the rats were tracheostomised and ventilated using pressure controlled ventilation (Siemens Servo 900C, Siemens-Solna, Sweden) with $15 \mathrm{~cm}$ $\mathrm{H}_{2} \mathrm{O}$ peak airway opening pressure (Pao), $0 \mathrm{cmH}_{2} \mathrm{O}$ PEEP, 30 breaths per minute, inspiratory/expiratory $(\mathrm{I} / \mathrm{E})=1 / 2$, and fraction of inspired oxygen $\left(\mathrm{FiO}_{2}\right)=1.0$. Intraperitoneal ketamine $(70-80 \mathrm{mg} / \mathrm{kg})$ was used for maintenance of anaesthesia and vecuronium bromide $(0.5 \mathrm{mg} / \mathrm{kg}$ Norcuron, Organon Teknika B.V., Boxtel, The Netherlands) for muscle relaxation, respectively. A 24 G catheter (Insyte-W, Becton Dickinson Infusion Therapy systems Inc., Utah, USA) was introduced into the left or right carotid artery after surgical exploration for drawing blood samples and arterial blood pressure monitoring (Mercury, Mennen Medical Inc., New York, USA) and disposable transducers (Deltran ABL system, Medical product Inc, Utah, USA) were used. Rectal temperature was monitored on the same monitor and kept constant at $37 \pm 1^{\circ} \mathrm{C}$ by using a heating pad. Blood gas analysis was performed ( $A B L$ 700, Radiometer, Copenhagen, Denmark) under anaerobic conditions immediately after sampling.

\section{Experimental Protocol}

The rats were subsequently separated into one of five groups according to ventilatory driving pressures, and, after drawing $0.5 \mathrm{~mL}$ blood for a baseline blood gas analysis, ventilation was set as follows in each group:

1. Group 15-0: $15 \mathrm{cmH}_{2} \mathrm{O} \mathrm{PaO}$ and $0 \mathrm{cmH}_{2} \mathrm{O}$ PEEP

2. Group 30-10: $30 \mathrm{cmH}_{2} \mathrm{O} P$ ao and $10 \mathrm{cmH}_{2} \mathrm{O}$ PEEP

3. Group 30-5: $30 \mathrm{cmH}_{2} \mathrm{O}$ Pao and $5 \mathrm{cmH}_{2} \mathrm{O}$ PEEP

4. Group 30-5\&RM: $30 \mathrm{cmH}_{2} \mathrm{O}$ Pao and $5 \mathrm{cmH}_{2} \mathrm{O}$ PEEP with additional $45 \mathrm{cmH}_{2} \mathrm{O}$ CPAP for 30 seconds in every 15 minutes

5. Group 45-0: $45 \mathrm{cmH}_{2} \mathrm{O}$ Pao and $0 \mathrm{cmH}_{2} \mathrm{O}$ PEEP.

The remaining ventilator parameters were kept as at baseline. Mean arterial pressure and ventilator parameters were measured continuously and recorded during the experiment every 5 minutes. We infused fluids when mean arterial blood pressure decreased by more than $20 \%$ of the baseline value. At the end of the experiment, $5.5 \mathrm{~mL}$ blood was drawn for blood gas analysis $(0.5 \mathrm{~mL})$ and cytokine level measurement $(5 \mathrm{~mL})$. Then, the animals were sacrificed using $120 \mathrm{mg} / \mathrm{kg}$ of sodium thiopental.

\section{Cytokine and Chemokine Levels}

Five millilitres of anti-coagulated blood that was drawn at the end of the experiment was centrifuged. The plasma was stored at $-80^{\circ} \mathrm{C}$ until cytokine and chemokine levels were measured. Tumour necrosis factor-a (TNF-a, Bender Medsystem, Diagnostic GmbH, A-1030-Rennweg, Vienna, Austria; assay range: $39-2500 \mathrm{pg} / \mathrm{mL}$ ), interleukin-1b (IL-1b, Bender Medsystem, Diagnostic $\mathrm{GmbH}, \mathrm{A}-1030-$ Rennweg, Vienna, Austria; assay range: $25.6-2500 \mathrm{pg} / \mathrm{mL}$ ), interleukin-6 (IL-6, Bender Medsystem, Diagnostic $\mathrm{GmbH}$, A-1030-Rennweg, Vienna, Austria; assay range: $31.25-2000 \mathrm{pg} / \mathrm{mL}$ ), monocyte chemoattractant protein-1 (MCP-1, Biosource Cyto Screen Int., Camarillo, CA, USA; assay range: $11.7-750 \mathrm{pg} / \mathrm{mL}$ ) levels were measured by enzyme-linked immunosorbent assay (ELISA) on the same day. These analyses were performed in a blinded fashion. There was no cross-reactivity between the measured variables.

\section{Morphologic evaluation}

The histopathological analysis was performed by a pathologist who was also blinded to the study groups. At the end of the study, lungs were removed and fixed with intratracheal instillation of $10 \%$ formalin, and also floated in formalin for at least 24 hours. The lungs were then serially sectioned in a caudal to coronal fashion into 2-3 parts from apex to base and embedded in paraffin; 2-3.5 $\mu \mathrm{m}$ sections from each paraffin block were taken at random and stained with haematoxylin and eosin. Ten random fields were read for each animal. The sections were evaluated according to a grading scale (0-4) for twelve different lesions (Table 1).

\section{Statistical analysis}

Data for morphologic evaluation scores, cytokine and chemokine levels, $\mathrm{pH}, \mathrm{PaO}_{2}, \mathrm{PaCO}_{2}$ and $\mathrm{MAP}$ values are reported as mean and standard deviation (SD). Intergroup comparisons were analysed by Kruskal Wallis ANOVA and Dunn's test was used for post-hoc analysis if $p<0.05$. Wilcoxon test was used for intragroup analysis.

\section{Results}

Thirty rats were used, with six in each of five groups. Mean arterial pressure (MAP) and fluid replacement during the study protocol are shown in Table 2. MAP and total fluid replacements were quite similar in each group through the study. Excluding group 45-0, $\mathrm{pH}, \mathrm{PaO}_{2}$, and $\mathrm{PaCO}_{2}$ values were similar during baseline and end-experiment conditions for the four remaining groups (Table 3 ).

As compared to baseline, $\mathrm{PaCO}_{2}$ values were significantly different at the end of the experiment only in group 45-0 $(p=0.03)$. Other intragroup changes in blood gases were not statistically significant.

After morphological evaluation of twelve lesions, statistical differences were observed in microscopic emphysema $(p=0.0058)$, congestion $(p=0.0091)$, alveolar haemorrhage $(p=0.016)$, interstitial polymorphonuclear leukocyte (PMN) infiltration $(p=0.0061)$, and hyaline membrane formation $(p=0.0001)$ parameters. While interstitial PMN infiltration and hyaline membrane formation differences were higher in group 
Table 1. Grading scale for morphologic evaluation.

\begin{tabular}{|c|c|c|c|c|c|}
\hline & 0 & 1 & 2 & 3 & 4 \\
\hline Microscopic Amphysema \& Atelectasia & None & $\begin{array}{l}\text { Focal in } 1 \text { or } \\
2 \text { fields }\end{array}$ & $\begin{array}{l}\text { Focal, in } 3 \text { or } \\
4 \text { fields }\end{array}$ & $\begin{array}{l}\text { Conspicuous in } 3 \text { or } \\
4 \text { fields }\end{array}$ & Diffuse \\
\hline Perivascular \& Perbronchial Oedema & None & $\begin{array}{l}\text { Focal in a } \\
\text { few fields }\end{array}$ & $\begin{array}{l}\text { Disseminated but } \\
\text { in a few fields }\end{array}$ & $\begin{array}{l}\text { Disseminated in } \\
\text { many fields }\end{array}$ & $\begin{array}{l}\text { Disseminated in } \\
\text { too many fields }\end{array}$ \\
\hline $\begin{array}{l}\text { Alveolar\& Perivascular } \\
\text { Haemorrhage }\end{array}$ & None & Focal, rare & $\begin{array}{l}\text { Disseminated, } \\
\text { septal }\end{array}$ & $\begin{array}{l}\text { filling the alveoli } \\
\text { focally }\end{array}$ & $\begin{array}{l}\text { filling the alveoli } \\
\text { diffusely }\end{array}$ \\
\hline Congestion & None & Focal, rare & $\begin{array}{l}\text { Focal but } \\
\text { significant }\end{array}$ & $\begin{array}{l}\text { Disseminated and } \\
\text { significant }\end{array}$ & $\begin{array}{l}\text { Disseminated and } \\
\text { enlarged }\end{array}$ \\
\hline Alveolar Oedema & None & $\begin{array}{l}\text { Focal in } 1 \text { or } \\
2 \text { fields }\end{array}$ & $\begin{array}{l}\text { Focal, in } 3 \text { or } \\
4 \text { fields }\end{array}$ & Disseminated & The whole lung \\
\hline Alveolar Mononuclear Cell Infiltration & None & Focal, a few & $\begin{array}{l}\text { Disseminated, } \\
\text { a few }\end{array}$ & $\begin{array}{l}\text { A few but in } \\
\text { all alveoli }\end{array}$ & Brisk in all alveoli \\
\hline Interstitial PMNs Infiltration & None & Focal, rare & $\begin{array}{l}\text { Disseminated } \\
\text { rare }\end{array}$ & $\begin{array}{l}\text { In all fields } \\
\text { but a few cells }\end{array}$ & $\begin{array}{l}\text { In all fields, } \\
\text { many cells }\end{array}$ \\
\hline Hyaline Membrane \& Type II Cells & None & $\begin{array}{c}\text { Focal in } 1 \text { or } \\
2 \text { fields }\end{array}$ & $\begin{array}{c}\text { Focal in } 3 \text { or } \\
4 \text { fields }\end{array}$ & Disseminated & The whole lung \\
\hline
\end{tabular}

Table 2. Mean arterial pressure (MAP), amount of fluid replacement during the study (mean $\pm S D$ ).

\begin{tabular}{|lcccccc|}
\hline & Group 15-0 & Group 30-10 & Group 30-5 & Group 30-5\&RM & Group 45-0 & P \\
\hline MAP $(\mathrm{mmHg})$ & $69.3 \pm 27$ & $67.1 \pm 21.35$ & $73.3 \pm 19.5$ & $71.5 \pm 18.1$ & $65.5 \pm 20.7$ & 0.96 \\
Fluid replacement $(\mathrm{mL})$ & $4.5 \pm 1.2$ & $4.9 \pm 1.4$ & $4.8 \pm 1.4$ & $4.2 \pm 1.6$ & $5.1 \pm 2$ & 0.81 \\
\hline p: Non parametric Kruskal-Wallis ANOVA (Intergroup statistics); MAP: & mean arterial pressure, RM: Recruitment Manoeuvre \\
\hline
\end{tabular}

Table 3. Intergroup analysis of blood gas parameters (mean \pm SD).

\begin{tabular}{|c|c|c|c|c|c|c|}
\hline & Group 15-0 & Group 30-10 & Group 30-5 & Group 30-5\&RM & Group 45-0 & $p$ \\
\hline $\mathrm{pH}-\mathrm{b}$ & $7.24 \pm 0.05$ & $7.17 \pm 0.06$ & $7.27 \pm 0.02$ & $7.20 \pm 0.05$ & $7.17 \pm 0.07 \#$ & 0.48 \\
\hline $\mathrm{pH}-\mathrm{e}$ & $7.23 \pm 0.05$ & $7.25 \pm 0.06$ & $7.26 \pm 0.02$ & $7.17 \pm 0.02$ & $7.25 \pm 0.04$ & 0.30 \\
\hline $\mathrm{PaO}_{2}-\mathrm{b}(\mathrm{mmHg})$ & $394 \pm 45$ & $492 \pm 56$ & $423 \pm 169$ & $473 \pm 28$ & $530 \pm 31$ & 0.22 \\
\hline $\mathrm{PaO}_{2}$-e $(\mathrm{mmHg})$ & $551 \pm 41$ & $473 \pm 69$ & $404 \pm 14$ & $475 \pm 32$ & $554 \pm 74$ & 0.22 \\
\hline $\mathrm{PaCO}_{2}-\mathrm{b}(\mathrm{mmHg})$ & $51 \pm 5$ & $69 \pm 3$ & $60 \pm 1.2$ & $61 \pm 7$ & $78 \pm 6$ & 0.07 \\
\hline $\mathrm{PaCO}_{2}-\mathrm{e}(\mathrm{mmHg})$ & $46 \pm 13$ & $58 \pm 15$ & $56.9 \pm 4$ & $64 \pm 5$ & $32 \pm 9$ & 0.15 \\
\hline
\end{tabular}

45-0 compared to all other groups, microscopic emphysema was lower only in group 15-0 compared to other groups. However, congestion was lower in both group 15-0 and group 30-5\&RM, but alveolar haemorrhage was higher in group 30$5 \& \mathrm{RM}$ and group 45-0. Figure 1 shows some morphologic changes of each group. When the cumulative mean values of the morphologic evaluation scores were analysed, a statistical difference was observed between group 45-0 vs. group 15-0 $(p<0.001)$ and group 45-0 vs. group 30-10 ( $<<0.01)$. There was no difference between the other groups (Table 4). According to the arithmetic mean values' of morphologic evaluation scores, the groups were categorised from mild to severe injury as follows: Group 15-0 < Group 30-10 < Group 30-5\&RM $<$ Group 30-5 < Group 45-0.

TNF- $\alpha$, MCP-1, IL-1 $\beta$, and IL-6 levels were higher in Group 45-0 and lower in group 30-5\&RM compared to all other groups. Intergroup statistical evaluation of each group for che- mokine and cytokines were significant $(p<0.0001)$. The differences for each chemokine and cytokine can be seen in Table 5. All measured cytokine and chemokine levels were lower in the recruitment manoeuvre group compared to the other groups.

\section{Discussion}

The main findings of our study were as follows: 1) Ventilation with low PEEP and intermittent RM (Group 30-5\&RM) caused the least systemic inflammatory response; 2) High PEEP with moderate Pao (Group 30-10) and low pressure ventilation groups (Group 15-0) caused significantly less morphologic injury in lungs than the high Pao group (Group 45-0).

Mechanical ventilation with high airway pressures can cause lung injury (13-15), which is appreciated as atelectasis, severe congestion, interstitial oedema, and alveolar oedema upon microscopic examination. The magnitude of peak airway 
Table 4. Morphologic evaluations (mean \pm SD).

\begin{tabular}{|lcccccc|}
\hline & Group 15-0 & Group 30-10 & Group 30-5 & Group 30-5\&RM & Group 45-0 & P \\
\hline Microscopic amphysema & $0.5 \pm 0.4$ & $4 \pm 0.34$ & $3.5 \pm 0.61$ & $3 \pm 0$ & $3 \pm 0$ & 0.0058 \\
Microscopic atelectasia & $0 \pm 0.16$ & $0 \pm 0$ & $1 \pm 0.4$ & $0 \pm 0.21$ & $0 \pm 0.16$ & 0.12 \\
Perivascular Oedema & $1 \pm 0.42$ & $1 \pm 0.47$ & $3 \pm 0.16$ & $2 \pm 0.16$ & $3 \pm 0.21$ & 0.053 \\
Perivascular haemorrhage & $0 \pm 0$ & $0 \pm 0.16$ & $0 \pm 0$ & $0 \pm 0$ & $0.5 \pm 0.22$ & 0.51 \\
Congestion & $1 \pm 0.34$ & $2 \pm 0.5$ & $3 \pm 0.4$ & $1 \pm 0$ & $3 \pm 0.44$ & 0.0091 \\
Alveolar Haemorrhage & $0 \pm 0$ & $0 \pm 0.16$ & $1 \pm 0.55$ & $2 \pm 0.11$ & $3 \pm 0.71$ & 0.016 \\
Alveolar oedema & $0 \pm 0.16$ & $0 \pm 0.66$ & $0 \pm 0.33$ & $1.5 \pm 0.22$ & $2 \pm 0.55$ & 0.064 \\
Alveolar mononuclear cell & $0.5 \pm 0.33$ & $0 \pm 0.21$ & $0.5 \pm 0.47$ & $2.0 \pm 0.34$ & $0.5 \pm 0.22$ & 0.32 \\
infiltration Peribronchial oedema & & & & & & \\
& $1.0 \pm 0$ & $1.0 \pm 0$ & $0 \pm 0.66$ & $1.0 \pm 0.16$ & $1.0 \pm 0$ & 0.95 \\
Interstitial PMNs infiltration & $1.0 \pm 0.3$ & $1.0 \pm 0.25$ & $1.5 \pm 0.42$ & $1.0 \pm 0.2$ & $3.0 \pm 0$ & 0.0061 \\
Hyaline membrane & $0 \pm 0$ & $0 \pm 0$ & $0 \pm 0$ & $0 \pm 0$ & $2.5 \pm 0.47$ & 0.0001 \\
Type II cells & $0 \pm 0$ & $0 \pm 0$ & $0 \pm 0$ & $0 \pm 0$ & $0 \pm 0.16$ & 0.4 \\
Total & $0 \pm 0.009^{*}$ & $0 \pm 0.14 \#$ & $1 \pm 0.16$ & $1 \pm 0.12$ & $2 \pm 0.16^{\star} \#$ & 0.0001 \\
\hline
\end{tabular}

p: Kruskal-Wallis ANOVA; *: Group 45-0 - Group 15-0: p<0.001; \#: Group 45-0 - Group 30-10: p<0.01; PMNs: Polymorphonuclear leukocytes; RM: Recruitment Manoeuvre

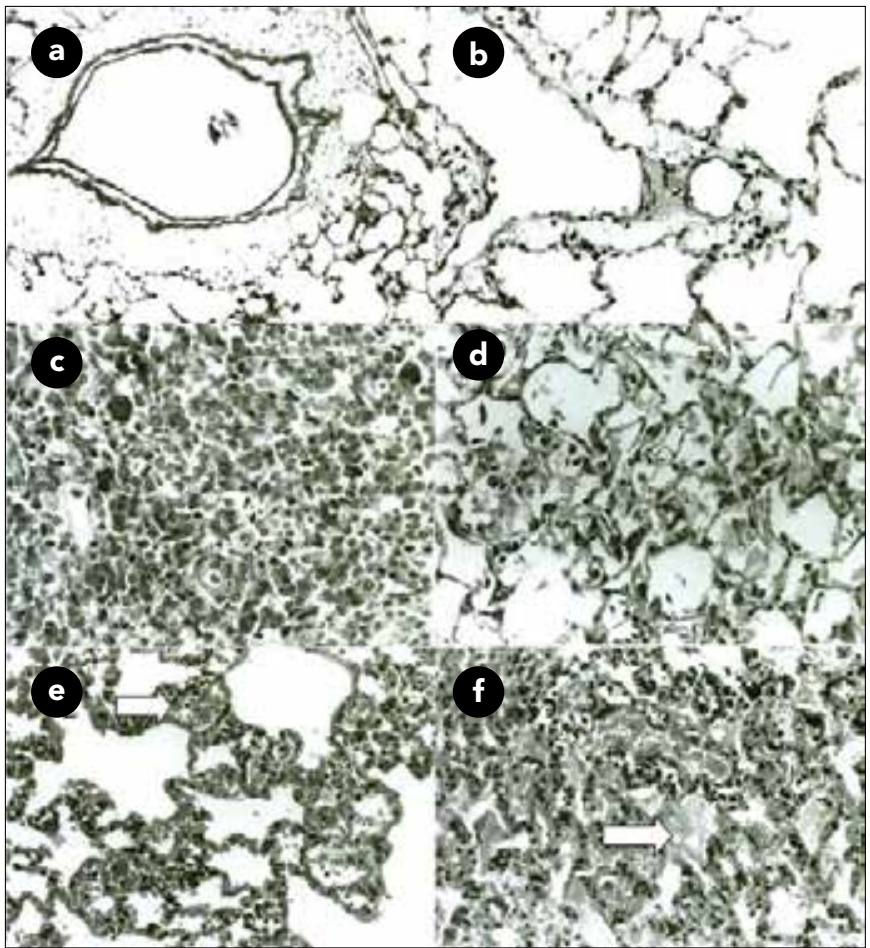

Figure 1. a-f. Fields from: (a) Group 15-0: Slight oedema in perivascular areas (Scored as Grade 1) (b) Group 3010: Conspicuous oedema in perivascular areas (Scored as Grade 3) (c) Group 30-5: Severe alveolar mononuclear cell infiltration (Grade 4) (d) Group 30-5\&RM: Mild alveolar mononuclear cell infiltration (Grade 2) (e) Group 45-0: Alveolar haemorrhage (Blank arrow) (Grade 4) (f) Group 450: Hyaline membrane formation (Blank arrow)

pressure and duration of mechanical ventilation are important parameters determining the degree of lung injury $(13,14)$. We decided to use $15 \mathrm{cmH}_{2} \mathrm{O}$ peak Pao as control, $30 \mathrm{cmH}_{2} \mathrm{O}$ peak Pao with $10 \mathrm{cmH}_{2} \mathrm{O}$ PEEP as a protective, and $45 \mathrm{cmH}_{2} \mathrm{O}$ peak
Pao as an injurious ventilation pressure in the study groups according to the study by Webb and Tierney (14). We used high levels of pressures $\left(45 \mathrm{cmH}_{2} \mathrm{O}\right)$ that were capable of inducing lung injury and low safe levels of pressures $\left(15 \mathrm{cmH}_{2} \mathrm{O}\right)$ as the control group for our protocol. This difference would allow us to differentiate the role of other mechanical ventilation strategies on lung injury.

The beneficial effect of $R$ in ARDS and ALI has been reported in animals by Cakar et al. and Van Der Kloot et al. (7, 16), and in humans by Lapinsky et al. (9) and Grasso et al. (17). The latter two studies demonstrated an improvement in oxygenation; however, Grasso et al. (17) found an increase in oxygenation only in early ARDS patients.

In our study, cytokine and chemokine levels were significantly different between groups. Group 30-5\&RM had the lowest levels of systemic inflammatory mediators, which were even lower than those in Group 15-0. However, Group 30-5, which has same level of ventilation pressures as Group 30-5\&RM (except $45 \mathrm{cmH}_{2} \mathrm{O}$ sustained inflation in every 15 minutes), produced a higher inflammatory response than Group 30-5\&RM and Group 15-0, but it was lower than Group 30-10. In a recent study, this finding was also observed, which shows that repeated $\mathrm{RM}$ at an inadequate/low PEEP of $2 \mathrm{cmH}_{2} \mathrm{O}$ aggravated VILI compared with RM at a high PEEP of $6 \mathrm{cmH}_{2} \mathrm{O}$ (18).

Naik et al. (19) evaluated different PEEP levels on preterm lambs and found that $4 \mathrm{cmH}_{2} \mathrm{O}$ PEEP caused less of an inflammatory response than 0 and $7 \mathrm{cmH}_{2} \mathrm{O}$ PEEP after 2 hours of ventilation. They also concluded that physiological amounts of PEEP, like 3-4 $\mathrm{cmH}_{2} \mathrm{O}$, are more protective against ventilatorinduced injury. Our results were similar to this study. We observed less of an inflammatory response with low PEEP but additive RM decreased the cytokine levels compared to the control group's (Group 15-0) cytokine levels.

Proinflammatory cytokines play a significant role in the pathogenesis of ventilator-induced lung injury by inducing 
Table 5. Cytokine and chemokine levels (mean \pm SD).

\begin{tabular}{|c|c|c|c|c|c|c|}
\hline & Group 15-0 & Group 30-10 & Group 30-5 & Group 30-5\&RM & Group 45-0 & $p$ \\
\hline TNF- $\alpha(p g / m L)$ & $700.0 \pm 529.6^{*}$ & $1169.1 \pm 282.1^{\star \star \star}$ & $958 \pm 325.7^{\star *}$ & $619.6 \pm 224.2^{\star}$ & $1757.9 \pm 162.81$ & $<0.0001$ \\
\hline MCP-1 (pg/mL) & $338.6 \pm 95.8^{\star}$ & $653.6 \pm 95.9^{R, C}$ & $522.2 \pm 182.7^{R R}, \mathrm{cC}$ & $335.4 \pm 120.0^{*}$ & $782.1 \pm 513.0$ & $<0.0001$ \\
\hline IL-1b (pg/mL) & $356.1 \pm 218.8^{\star}$ & $630.2 \pm 85.1 *, R, C$ & $672 \pm 78.1^{*}, R, C$ & $284.4 \pm 102.5^{\star}$ & $1115.4 \pm 464.4$ & $<0.0001$ \\
\hline IL-6 (pg/mL) & $500.4 \pm 67.2^{\star}$ & $680.4 \pm 136.8^{R, c C}$ & $561.3 \pm 47.1^{\star \star}, R$ & $258 \pm 78.3^{\star}$ & $841.2 \pm 554.7$ & $<0.0001$ \\
\hline
\end{tabular}

p: Kruskal-Wallis ANOVA, RM: Recruitment Manoeuvre; * vs. Group45-0 is $p<0.001$; *夫 vs. Group45-0 is $p<0.01$; ${ }^{\star \star \star}$ vs. Group45-0 is $p<0.05$; $R$ vs. Group30-5\&RM is $p<0.001$; RR vs. Group30-5\&RM is $p<0.05 ; C$ vs. Group15-0 is $p<0.001 ; C C$ vs. Group15-0 is $p<0.01$

other proinflammatory mediators, sequestration and accumulation of neutrophils and increasing vascular permeability (20). We have not performed lung lavage to evaluate the vascular permeability with protein amount and the inflammatory cell recruitment but morphometry showed us that congestion and interstitial PMN infiltration was significantly lower in Group 15-0 and Group 30-5\&RM. In our study, we evaluated the role of different ventilatory strategies on systemic inflammatory response by using the proinflammatory cytokines, especially IL-1 $\beta$, IL-6, and TNF- $\alpha$, as they have been reported to also be increased in adult lung injury models (21), and they are the early markers of injury.

To determine whether different ventilation strategies change the expression of these biological markers of lung injury, we used two different levels of PEEP and RM including ventilation strategies. Our data indicates that $5 \mathrm{cmH}_{2} \mathrm{O}$ PEEP\&RM is more protective against inflammatory response compared to other groups, but, according to morphometry, Group 30-5\&RM came after Group 15-0 and Group 30-10. However, 0 and $10 \mathrm{cmH}_{2} \mathrm{O}$ PEEP may cause lung injury by different mechanisms. The morphology is consistent with observations in animal models that with $0 \mathrm{cmH}_{2} \mathrm{O}$ of PEEP the lung was being repetitiously opened and closed, leading to increased surfactant inactivation, neutrophil infiltration, and progressive lung injury (22). Ventilation with $10 \mathrm{cmH}_{2} \mathrm{O}$ PEEP causes over distension with stress failure of pulmonary capillaries causing injury (23). The use of PEEP in low levels $(5 \mathrm{~cm}$ $\mathrm{H}_{2} \mathrm{O}$ ) with intermittent sustained inflation may protect the lung from injury because it minimises the inflammatory response which is caused by ventilation. Expression of MCP-1 was the lowest in the Group 30-5\&RM, as were TNF- $\alpha$, IL-1 $\beta$ and IL-6 levels. MCP-1 levels have been shown to be correlated with 7 to 21 days injury levels in lungs (24). These high levels of chemokines and pro-inflammatory cytokines may also increase lung damage incidence in long-term ventilation because of biotrauma as a component of VILI.

Large volumetric fluctuations delivered as a sigh were shown to improve surfactant function (25). A sustained inflation delivered as an RM may lead to the same improvement in surfactant activity, which may have a protective role against shear stress and inflammatory response. These results also pointed out that RM could be a protective manoeuvre on healthy regions of the lung during mechanical ventilation, since ALI and ARDS are heterogeneous lung diseases and consist of both healthy and injured lung regions. The protective ventilation strategies for intact lung regions are just as important as for the injured areas.
In our study, lung injury was demonstrated by morphologic evaluation, blood gas changes and inflammatory response. However, the wet weight/dry weight ratio of lungs and protein concentration changes in alveolar fluid, which are among the evaluation criteria of VILI (26), were not evaluated; this could have strengthened our findings if had been done. Although this study has major limitations (which are not concerning the findings) the findings from this study about potentiation of VILI during different ventilatory strategies will provide rationale for further studies.

In conclusion, our study demonstrates that mechanical ventilation with high pressures in an intact lung is injurious and different ventilatory strategies influence this injury. We tried to minimise the lung injury by using low PEEP and RM. However, indicators of lung injury still increased with mechanical ventilation. Our results are compatible with previous data. In a recent study it was demonstrated that VILI production was obvious when high tidal volumes with low levels of PEEP are applied as a ventilation strategy (27). Our observation that mechanical ventilation induces pro-inflammatory cytokines could be provocative for clinical perspectives. This suggests that these cytokines may play a significant role in the pathogenesis of chronic lung injury in long-term ventilation on intact lungs. Van Marter et al. (28) identified enrolment to the ventilation as a major risk factor for chronic lung disease development. The use of low levels of PEEP with intermittent sustained inflation may reduce the lung injury not only with a reduced risk of atelectrauma but also with biotrauma in healthy lung regions.

Ethics Committee Approval: Ethics committee approval was received for this study from İstanbul University Experimental Medicine and Research Institute Animal Investigation Committee: $1561 / 16012001$

Informed Consent: N/A

Peer-review: Externally peer-reviewed.

Author contributions: Concept - N.C., I.O.A., L.T.; Design - I.O.A., P.E.O., S.T.; Supervision - N.C., L.T.; Resource - D.Y., K.A.; Materials - i.O.A., K.A.; Data Collection\&/or Processing - i.O.A., K.A.; Analysis\&/or Interpretation D.Y., B.K., i.O.A.; Literature Search - I.O.A., P.E.O., K.A.; Writing - I.O.A., N.C., A.B.; Critical Reviews - N.C., L.T., I.O.A.

Conflict of Interest: No conflict of interest was declared by the authors.

Financial Disclosure: This study was performed in the experimental laboratory founded by Prof. Dr. Kutay Akpir at Istanbul University, Anesthesiology \& Intensive Care Department and supported by Research Fund of Istanbul University. Project Number: 1561/16012001. 


\section{References}

1. International consensus conferences in intensive care medicine. Ventilator-associated lung injury in ARDS. American Thoracic Society, European Society of Intensive Care Medicine, Societé de Réanimation Langue Française. Intensive Care Med 1999;25:1444-52.

2. Ventilation with lower tidal volumes as compared with traditional tidal volumes for acute lung injury and the acute respiratory distress syndrome. The Acute Respiratory Distress Syndrome Network. N Engl J Med 2000;342:1301-8. [CrossRef]

3. Amato MB, Barbas CS, Medeiros DM, Magaldi RB, Schettino GP, Lorenzi-Filho $\mathrm{G}$, et al. Effect of protective ventilation strategy on mortality in the acute respiratory distress syndrome. $N$ Engl J Med 1998;338:347-54. [CrossRef]

4. Stewart TE, Meade MO, Cook DJ, Granton JT, Hodder RV, Lapinsky $\mathrm{SE}$, et al. Evaluation of a ventilation strategy to prevent barotrauma in patients at high risk for acute respiratory distress syndrome. Pressure- and Volume-Limited Ventilation Strategy Group. N Engl J Med 1998;338:355-61. [CrossRef]

5. Brochard L, Roudot-Thoraval F, Roupie E, Delclaux C, Chastre J, Fernandez-Mondéjar $E$, et al. Tidal volume reduction for prevention of ventilator-induced lung injury in acute respiratory distress syndrome. The Multicenter Trail Group on Tidal Volume reduction in ARDS. Am J Respir Crit Care Med 1998;158:1831-8. [CrossRef]

6. Pelosi $\mathrm{P}$, Cadringher $\mathrm{P}$, Bottino N, Panigada M, Carrieri F, Riva E, et al. Sigh in acute respiratory distress syndrome. Am J Respir Crit Care Med 1999;159:872-80. [CrossRef]

7. Cakar N, der Kloot TV, Youngblood M, Adams A, Nahum A. Oxygenation response to a recruitment maneuver during supine and prone positions in an oleic-acid lung injury model. Am J Respir Crit Care Med 2000;161:1949-56. [CrossRef]

8. Muscedere JG, Mullen JB, Gan K, Slutsky AS. Tidal ventilation at low airway pressures can augment lung injury. Am J Respir Crit Care Med 1994;149:1327-34. [CrossRef]

9. Lapinsky SE, Aubin M, Mehta S, Boiteau P, Slutsky AS. Safety and efficacy of a sustained inflation for alveolar recruitment in adults with respiratory failure. Int Care Med 1999;25:1295-301. [CrossRef]

10. Rimensberger PC, Pristine G, Mullen BM, Cox PN, Slutsky AS. Lung recruitment during small tidal volume ventilation allows minimal positive end-expiratory pressure without augmenting lung injury. Crit Care Med 1999;27:1940-5. [CrossRef]

11. Gattinoni L, Pelosi P, Vitale G, Pesenti A, D'Andrea L, Mascheroni $\mathrm{D}$. Body position changes redistribute lung computed-tomographic density in patients with acute respiratory failure. Anesthesiology 1991;74:15-23. [CrossRef]

12. Cakar N, Akinci O, Tugrul S, Ozcan PE, Esen F, Eraksoy H, et al. Recruitment maneuver: does it promote bacterial translocation? Crit Care Med 2002;30:2103-6. [CrossRef]

13. Dreyfuss D, Basset G, Soler P, Saumon G. Intermittent positivepressure hyperventilation with high inflation pressures produces pulmonary microvascular injury in rats. Am Rev Respir Dis $1985 ; 132: 880-4$.
14. Webb HH, Tierney DF. Experimental pulmonary edema due to intermittent positive pressure ventilation with high inflation pressures: protection by positive end-expiratory pressure. Am Rev Respir Dis 1974;110:556-65.

15. John E, Ermocilla R, Golden J, McDevitt M, Cassady G. Effects of intermittent positive-pressure ventilation on lungs of normal rabbits. Br J Exp Pathol 1980;61:315-23.

16. Kloot TE, Blanch L, Melynne Youngblood A, Weinert C, Adams $A B$, Marini JJ, et al. Recruitment maneuvers in three experimental models of acute lung injury. Effect on lung volume and gas exchange. Am J Respir Crit Care Med 2000;161:1485-94. [CrossRef]

17. Grasso S, Mascia L, Del Turco M, Malacarne P, Giunta F, Brochard $L$, et al. Effect of recruiting maneuvers in patients with acute respiratory distress syndrome ventilated with protective ventilatory strategy. Anesthsiology 2002;96:795-802. [CrossRef]

18. Ko SC, Zhang H, Haitsma JJ, Cheng KC, Li CF, Slutsky AS. Effects of PEEP levels following repeated recruitment maneuvers on ventilator-induced lung injury. Acta Anaesthesiol Scand 2008;52:514-21. [CrossRef]

19. Naik AS, Kallapur SG, Bachurski CJ, Jobe AH, Michna J, Kramer $B W$, et al. Effects of ventilation with different positive end-expiratory pressures on cytokine expression in the preterm lamb lung. Am J Respir Crit Care Med 2001;164:494-8. [CrossRef]

20. Pittet JF, Mackersie RC, Martin TR, Matthay MA. Biological markers of acute lung injury: prognostic and pathogenetic significance. Am J Respir Crit Care Med 1997;155:1187-205. [CrossRef]

21. Ranieri VM, Suter PM, Tortorella C, De Tullio R, Dayer JM, Brienza $A$, et al. Effect of mechanical ventilation on inflammatory mediators in patients with acute respiratory distress syndrome: a randomized controlled trial. JAMA 1999;282:54-61. [CrossRef]

22. Muscedere JG, Mullen JB, Gan K, Slutsky AS. Tidal ventilation at low airway pressures can augment lung injury. Am J Respir Crit Care Med 1994;149:1327-34. [CrossRef]

23. Tremblay L, Valenza F, Ribeiro SP, Li J, Slutsky AS. Injurious ventivlatory strategies increase cytokines and c-fos m-RNA expression in an isolated rat lung model. J Clin Invest 1997;99:944-52. [CrossRef]

24. Goodman RB, Strieter RM, Martin DP, Steinberg KP, Milberg JA, Maunder RJ, et al. Inflammatory cytokines in patients with persistence of the acute respiratory distress syndrome. Am J Respir Crit Care Med 1996;154:602-11. [CrossRef]

25. Nicholas TE, Power JHT, Barr HA. The pulmonary consequences of a deep breath. Respir Physiol 1982;49:315-24. [CrossRef]

26. Dreyfuss $D$, Saumon $G$. Ventilator-induced lung injury: lessons from experimental studies. Am J Respir Crit Care Med 1998;157:294-323. [CrossRef]

27. Seah AS, Grant KA, Aliyeva M, Allen GB, Bates JH. Quantifying the Roles of Tidal Volume and PEEP in the Pathogenesis of Ventilator-Induced Lung Injury. Ann Biomed Eng 2011;39: 1505-16. [CrossRef]

28. Van Marter LJ, Allred EN, Pagano M, Sanocka U, Parad R, Moore $M$, et al. Do clinical markers of barotrauma and oxygen toxicity explain interhospital variation in rates of chronic lung disease? The Neonatology Committee for the Developmental Network. Pediatrics 2000;105:1194-201. [CrossRef] 